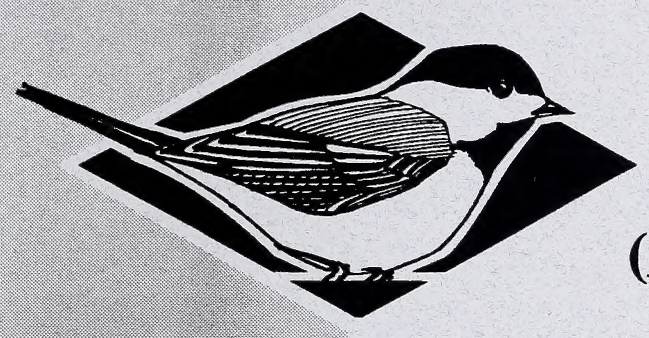

whelfis

macement

Dhustot

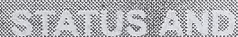

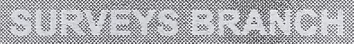

\section{Status of the Burrowing Owl}

(Speotyto cunicularia hypugaea) in Alberta

\section{Troy I. Wellicome}

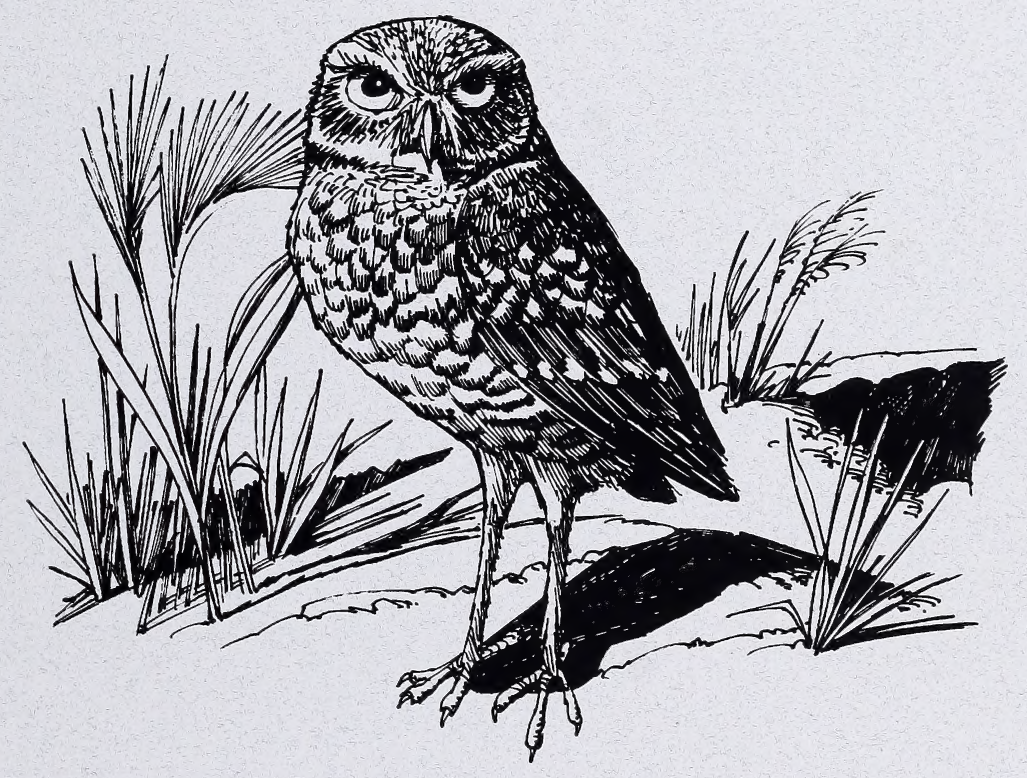

Alberta Wildlife Status Report No. 11 
Digitized by the Internet Archive in 2015 


\title{
Status of the Burrowing Owl \\ (Speotyto cunicularia hypugaea) in Alberta
}

\author{
Troy I. Wellicome
}

Alberta Wildlife Status Report No. 11

Published By:
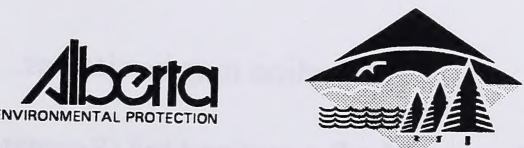
Publication No. T/374

ISBN: 0-7732-5136-7

ISSN: $1206-4912$

Series Editor: David R. C. Prescott

Illustrations: Brian Huffman

For copies of this report, contact:

Information Centre - Publications

Alberta Environmental Protection

Natural Resources Service

Main Floor, Bramalea Building 9920 - 108 Street

Edmonton, Alberta, Canada T5K 2M4

Telephone: (403) 422-2079

\section{OR}

Communications Division

Alberta Environmental Protection

\#100, 3115 - 12 Street NE

Calgary, Alberta, Canada T2E 7J2

Telephone: (403) 297-3362

This publication may be cited as:

Wellicome, T. I. 1997. Status of the Burrowing Owl (Speotyto cunicularia hypugaea) in Alberta. Alberta Environmental Protection, Wildlife Management Division, Wildlife Status Report No. 11, Edmonton, AB. 21 pp. 


\section{PREFACE}

Every five years, the Wildlife Management Division of Alberta Natural Resources Service reviews the status of wildlife species in Alberta. These overviews, which have been conducted in 1991 and 1996, assign individual species to "color" lists which reflect the perceived level of risk to populations which occur in the province. Such designations are determined from extensive consultations with professional and amateur biologists, and from a variety of readily-available sources of population data. A primary objective of these reviews is to identify species which may be considered for more detailed status determinations.

The Alberta Wildlife Status Report Series is an extension of the 1996 Status of Alberta Wildlife review process, and provides comprehensive current summaries of the biological status of selected wildlife species in Alberta. Priority is given to species that are potentially at risk in the province (Red or Blue listed), that are of uncertain status (Status Undetermined), or which are considered to be at risk at a national level by the Committee on the Status of Endangered Wildlife in Canada (COSEWIC).

Reports in this series are published and distributed by the Wildlife Management Division of Alberta Environmental Protection, and are intended to provide detailed and up-to-date information which will be useful to resource professionals for managing populations of species and their habitats in the province. The reports are also designed to provide current information which will assist the proposed Alberta Endangered Species Conservation Committee to identify species that may be formally designated as endangered or threatened under the Alberta Wildlife Act. To achieve these goals, the reports have been authored and/or reviewed by individuals with unique local expertise in the biology and management of each species. 


\section{EXECUTIVE SUMMARY}

The Burrowing Owl is currently listed as an "endangered" species throughout its range in Canada, and is designated as "endangered" under the Alberta Wildlife Act. A review of the status of the Burrowing Owl in Alberta was undertaken as a step in updating the provincial status of this species.

The Burrowing Owl is a summer resident in Canada, breeding in the mixed- and short-grass prairie regions. The owl requires an adequate nest burrow in an open area immediately surrounded by short vegetation, and enough permanent vegetative cover and tall grasses within its foraging home range to provide a sufficient amount of prey. Although the quantity and quality of such grassland habitat has declined substantially on much of the Canadian prairies, habitat modification has been least severe in Alberta, where large areas of potentially suitable habitat have been maintained to support livestock grazing rather than being converted to annual crops. Concurrent with decreases in grassland habitat have been increases in habitat fragmentation, pesticide use, and predator populations - all of which may have negatively affected Burrowing Owl populations. The determination of potential limiting factors during the non-breeding season has been hampered by a lack of information on the migration routes and the location of wintering grounds for Canada's Burrowing Owls.

The breeding population in Alberta is now estimated to be less than 800 pairs, compared with estimates of over 1500 pairs in 1978 (Wellicome and Haug 1995) and approximately 1000 pairs in 1990 (Haug and Didiuk 1991). The provincial range has also contracted noticeably over the last few decades. During the present decade, extensive reports from rural landowners documented a steady yearly decline in owl numbers, and intensive surveys on sites near Hanna provided supporting evidence for this decline. Unfortunately, the exact causes of the population decrease are, as yet, unknown. Unless the population trend is reversed, however, the Burrowing Owl is likely to be extirpated from the province, and from the entire country, within a couple of decades. 


\section{ACKNOWLEDGEMENTS}

Many thanks to Kort Clayton and Josef Schmutz (University of Saskatchewan) for providing unpublished data, and Steve Brechtel (Alberta Natural Resources Service), Ken De Smet (Manitoba Natural Resources), Geoff Holroyd and Helen Trefry (Canadian Wildlife Service), David Low (British Columbia Environment), Josef Schmutz, Kort Clayton, David Scobie (Operation Grassland Community), and Dan Wood (volunteer, Castor, Alberta) for offering personal communications. Thanks to David Prescott, Steve Brechtel (Alberta Natural Resources Service), Josef Schmutz, and David Scobie for reviewing this report. The contributions of Nature Saskatchewan (Operation Burrowing Owl Saskatchewan) and the Alberta Fish and Game Association (Operation Burrowing Owl Alberta) are greatly appreciated. I also thank Jane Horb for producing the maps.

The project was funded by the Wildlife Management Enhancement Fund of Alberta Natural Resources Service and the Alberta Conservation Association. 


\section{TABLE OF CONTENTS}

PREFACE iii

EXECUTIVE SUMMARY iv

ACKNOWLEDGEMENTS $\mathrm{v}$

INTRODUCTION 1

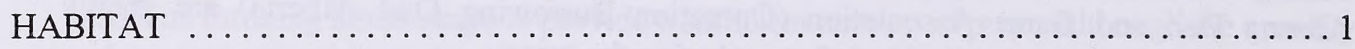

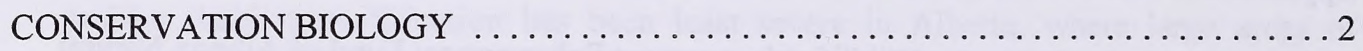

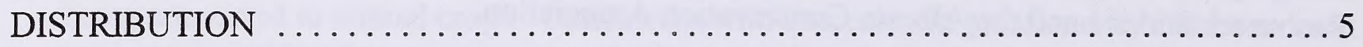

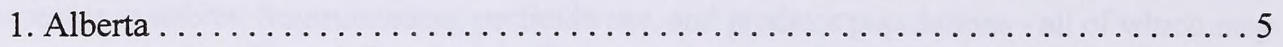

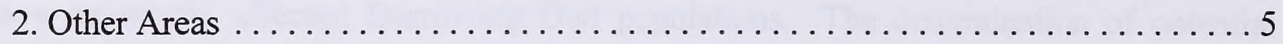

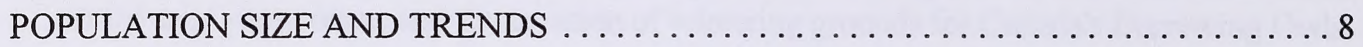

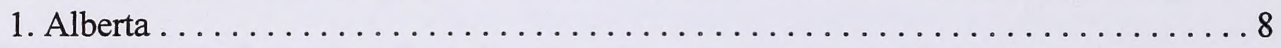

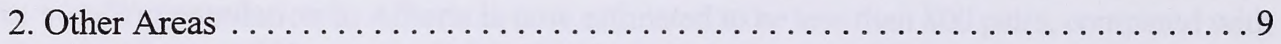

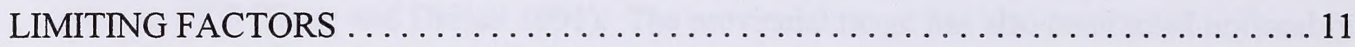

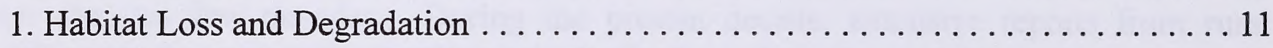

2. Mortality on Migration or Wintering Grounds $\ldots \ldots \ldots \ldots \ldots \ldots \ldots \ldots \ldots \ldots \ldots \ldots \ldots$

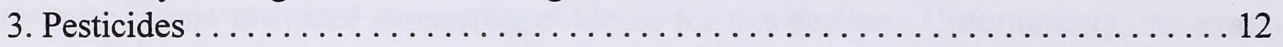

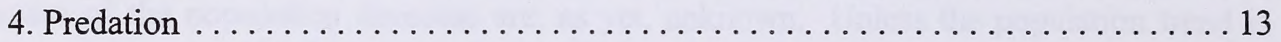

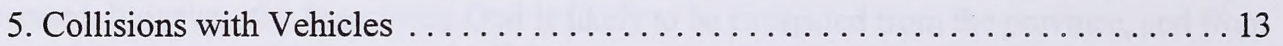

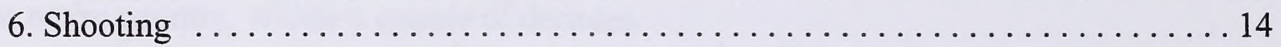

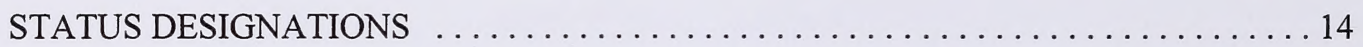

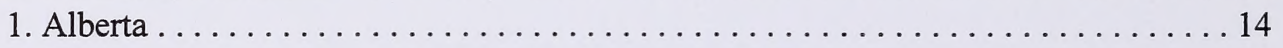

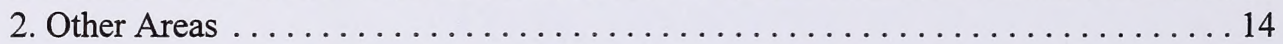

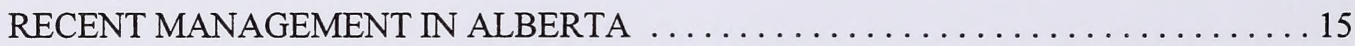

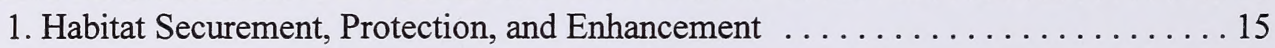

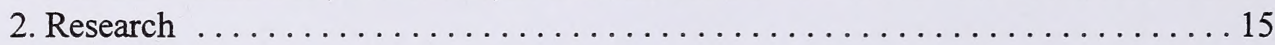

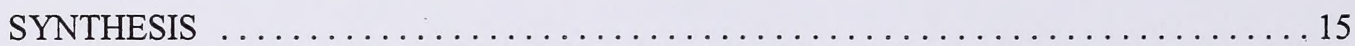

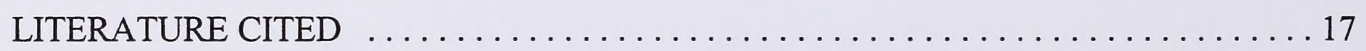

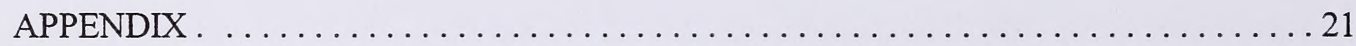




\section{INTRODUCTION}

Two subspecies of Burrowing Owl occur in North America: the Florida Burrowing Owl (Speotyto cunicularia floridans), which is found primarily in Florida and on the Bahama Islands, and the western Burrowing Owl (․․ $\underline{\text { c. }}$ hypugaea), which is found throughout Mexico, the western United States, and southwestern Canada (Haug et al. 1993). Although populations of the Florida Burrowing Owl are stable and at no risk of extinction, there has been widespread national and international concern in recent years about declines in populations of the western Burrowing Owl. The majority of jurisdictions within the western Burrowing Owl's range give it special status above that of regular protection (Haug et al. 1993).

In Alberta, the Burrowing Owl is classified as "endangered" " under the Wildlife Act, and is included on the "Red List" of species that are at risk in the province (Alberta Wildlife Management Division 1996). The present report summarizes current information relevant to the status of this species in Alberta.

\section{HABITAT}

Specific habitat characteristics of sites occupied by Burrowing Owls vary with geographic location. The three basic attributes of nesting habitat for the western Burrowing Owl are available nest burrows, short or sparse vegetation, and open terrain (Zarn 1974). On the Canadian prairies, nests are found on flat to gently undulating, treeless plains (Wedgwood 1978). Ground squirrel (Spermophilus spp.) or Black-tailed Prairie Dog (Cynomys ludovicianus) burrows, Badger (Taxidea taxus) excavations, and occasionally fox (Vulpes spp.) dens are used for nesting, roosting, and caching food.
Burrowing Owls are most abundant in the mixed-grass and dry mixed-grass ecoregions of Alberta, and are seldom found in the aspen parkland and fescue grass ecoregions of the province (Scobie 1993). The land systems selected for nesting have not been examined in Alberta, but in Saskatchewan, most of 665 burrow sites examined were located on lacustrine, solonetzic, saline, and alluvium land systems with few rocks. In particular, owl densities on lacustrine systems were five times higher than those in the second most highly selected category, solonetzic soils (Harris and Lamont 1985). Vegetation type does not appear to be important as long as it is kept short or sparse by soil or climatic conditions, grazing, haying, mowing, or burning (Wedgwood 1978). With present land-use practices, areas grazed by livestock provide the vast majority of nesting habitat for Burrowing Owls in Canada. On a finer scale, owls in Saskatchewan seem to prefer nesting in loam or clay soils (Hjertaas and Lyon 1987).

In July of 1989 , on a study area near Hanna, AB, Schmutz (1989) compared three attributes of occupied nest sites to those of sites located one kilometer north of occupied sites. Grasshopper abundance, weight of vegetation, and number of mammal burrows did not differ significantly between the occupied sites and the systematically-chosen, unoccupied sites, suggesting that local site selection by Burrowing Owls was not based on any of these three components of habitat near their nest burrows. Conversely, on the Regina Plain in Saskatchewan, owls selected certain pastures over others based on specific physical and biotic parameters: occupied pastures were more level, more likely to be grazed, and had a greater density of ground squirrel holes than did unoccupied pastures (James et al. 1991).

* See Appendix for definitions of selected status designations. 
Diurnal foraging by Burrowing Owls is almost exclusively for insects, and is confined to the vicinity of the nest burrow and, hence, usually to pasture (Gleason 1978, Haug and Oliphant 1990). More important for foraging owls is the habitat they use at night when hunting small mammals (Haug and Oliphant 1990, Plumpton 1992), which comprise the majority of their caloric intake (Schmutz et al. 1991b). However, no information is available on nocturnal foraging by Burrowing Owls in Alberta. The only telemetry study of adult foraging was conducted in an intensivelyfarmed area south of Saskatoon, SK (Haug and Oliphant 1990). In this study, peak foraging activity and maximum distances from nests occurred at night between 2030 and $0630 \mathrm{~h}$. Minimum foraging home-range size for six radio-tagged males averaged $2.41 \mathrm{~km}^{2}$ (min. $=0.14 \mathrm{~km}^{2}, \max .=4.81 \mathrm{~km}^{2}$ ). Maximum distance from the nest while foraging averaged $1.73 \mathrm{~km}$ for five nests. When further than 50 $\mathrm{m}$ from the nest burrow, radio-tagged males foraged over uncultivated fields, ungrazed areas, and roadside habitats more often then expected by chance (Haug and Oliphant 1990). These habitat types had dense, permanent vegetation greater than $30 \mathrm{~cm}$ in height. Small mammal trapping in Avonlea, SK, showed that these habitats had high densities of Deer Mice (Peromyscus maniculatus) and Meadow Voles (Microtus pennsylvanicus) compared with other habitats such as seeded fields and heavily-grazed pastures (Wellicome 1994). Accordingly, owls tended to avoid crop and pasture, and used fallow in proportion to its availability (Haug and Oliphant 1990). It appears, therefore, that owls concentrated their foraging in habitats with high small mammal abundances. So, in addition to requiring an open area with an adequate nest burrow immediately surrounded by short vegetation, Burrowing Owls need enough permanent cover and tall vegetation ( 30 to $60 \mathrm{~cm}$ ) within their foraging home range to supply a sufficient amount of small mammals and other prey.

Little is known about the habitat requirements of Burrowing Owls on their wintering grounds. However, the availability of burrows is assumed to be one important component of habitat use, as Burrowing Owls in Mexico and Texas have been observed only in association with burrows.

\section{CONSERVATION BIOLOGY}

The Burrowing Owl is a generalist predator (Plumpton and Lutz 1993) of small vertebrates and invertebrates. Early in the breeding season, many dung and carrion beetles are eaten, and deer mice and voles constitute upwards of $90 \%$ of the diet by weight (Schmutz et al. 1991b, Haug et al. 1993). Later in the season, in some years, grasshoppers become more important in the diet, comprising up to $35 \%$ of the mass of consumed prey. Grasshoppers may be very important prey for fledglings learning to hunt on their own (Haug et al. 1993).

The Burrowing Owl is a small owl, weighing between 125 and 185 grams. Neither plumage nor size differ appreciably between the sexes (Plumpton and Lutz 1994; J. Schmutz, unpubl. data). Both sexes are capable of breeding at 10 months of age (Haug et al. 1993). Their longevity in Alberta is not known, although many of the breeders in Saskatchewan were first-year birds and only five percent were known to be at least five years old (T. Wellicome, unpubl. data). The oldest owl known in North America, based on banding returns, was eight years old $(\mathrm{H}$. Trefry, pers. comm.). 
Burrowing Owls typically arrive in Alberta between early April and early May, depending on the harshness of spring weather. The earliest confirmed sightings were on 31 March, 1995, and 2 April, 1997 - both south of Brooks, Alberta (D. Scobie, pers. comm.). Males choose a nest burrow and advertise for females using their primary call, a two-note coo coooo (Haug et al. 1993). Males begin feeding their mates before egg laying and continue to do so until brooding of young is complete, at which time both sexes begin to hunt (Bent 1938). The pair lines the nest chamber and tunnel with dried, shredded manure. Egg laying begins in Alberta between late April and late May, depending on arrival times (D. Wood, pers. comm.). Because Burrowing Owls in Alberta have been studied only in natural nest burrows, clutch size and many other reproductive parameters are unknown; however, data have been collected for owls nesting at a similar latitude in artificial nest boxes in Saskatchewan. Clutches near Regina average approximately nine eggs and range between six and 11 eggs. Eggs are laid at 36-hour intervals (Wellicome in press). Clutch size decreases with date of laying, so that late clutches are three to five eggs smaller than early clutches. First eggs hatch about 30 days after clutch initiation, and on average $90 \%$ of eggs hatch. Last eggs hatch between two and six days after first eggs, resulting in an age disparity among the nestlings. The hatchlings are altricial (immobile, with eyes closed and fed by the parents), and starvation and cannibalism often occur during natural food shortages. Young begin moving to nearby burrows when they are approximately 25 days of age, and are capable of sustained flight at 50 days. They become independent of the adults between 60 and 70 days after hatching (K. Clayton, unpubl. data; T. Wellicome, unpubl. data).
Owls nesting in the Hanna site, which has restricted cultivation ( $15 \%$ of land area) and moderate grazing pressure, have exhibited higher reproductive output (Schmutz et al. 1991b) than have owls in Manitoba and Saskatchewan (Hjertaas et al. 1995). Schmutz et al. (1991b) attributed the difference in breeding success to a difference in natural prey supply among the areas. However, over the last 11 years, reproductive output (the number of fledglings per successful nest) has declined in the Hanna area (Clayton and Schmutz 1995; Figure 1). The cause of this decline in reproductive output is not known.

The reproductive effects of one factor, food supply, were investigated experimentally at Avonlea, SK. Provisioning of extra food to some pairs during egg laying had little effect on clutch size (Wellicome in press), but supplemental feeding during the nestling period resulted in the production of $17 \%$, $190 \%$, and $38 \%$ more young than in unfed nests (1992, 1993, and 1996, respectively; Wellicome et al. in press). Food intake was thus more limiting during brood rearing than during egg laying. Starvation was quite prevalent in nests that did not receive extra food, and probably explains the discrepancy between the number of eggs that Burrowing Owls lay and the number of young they usually fledge.

Because Burrowing Owls are small and do not nest in trees like most other raptors, they have many potential predators. The predators are of two general types: (1) predators that enter or dig up burrows, eating eggs, nestlings, and/or adult females; and (2) predators that prey on older nestlings and adults when they are above-ground. In Alberta, animals that can potentially access nest chambers are Badgers, foxes, Striped Skunks (Mephitus mephitus), Least and Long-tailed Weasels (Mustela 


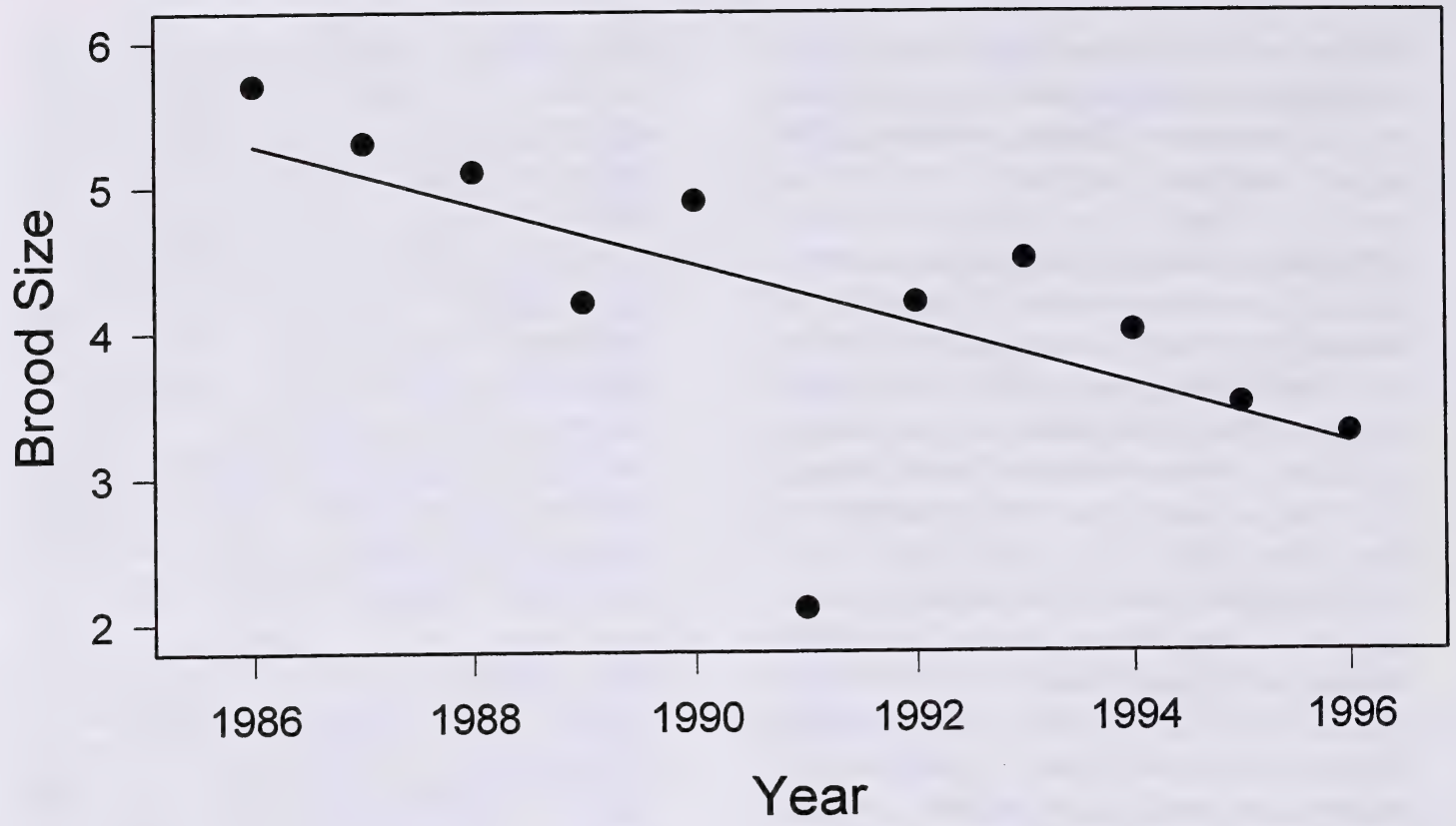

Figure 1. Decrease in average brood size (number of birds near fledging age per successful nest) over time in the Hanna study area, Alberta (modified from Clayton and Schmutz 1995). Line drawn by linear regression.

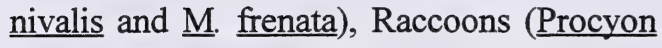
lotor), Prairie Rattlesnakes (Crotalus $\underline{v}$. viridis), and Bull Snakes (Pituophis melanoleucus sayi). Animals that mainly catch owls above-ground are Coyotes (Canis latrans), Domestic Dogs (‥ familiaris) and Cats (Felis domesticus), Swainson's Hawks (Buteo swainsoni), Ferruginous Hawks ( $\underline{\text { B. }}$. regalis), Red-tailed Hawks (B. jamaicensis), Great Horned Owls (Bubo virginianus), Northern Harriers (Circus cyaneus), Shorteared Owls (Asio flammeus), and Prairie Falcons (Falco mexicanus). Badgers, Striped Skunks and Long-tailed Weasels seem to present the most serious threats to female Burrowing Owls and their eggs/nestlings, whereas avian predators cause the majority of mortalities in adult males and fledglings.
Nest-predation rates have not been quantified over the entire breeding season in Alberta. On the major study area near Hanna, research typically begins in June, when owls are midway through incubation. For the period between mid-incubation and fledging, nestpredation rates are thought to be less than five percent (D. Wood, pers. comm.). In the Regina Plain, where data on natural burrows have been collected for entire breeding seasons, 10 of 19 nests (53\%) in 1995, and three of $16(19 \%)$ in 1996 , were lost to fossorial mammals (Wellicome et al. in press). Badgers were responsible for most predation events, and in some cases killed incubating or brooding females. Adult female survival between spring arrival and the fledging of young ranged from 88 to $100 \%$ between 1992 and 1996. All but one of the female 
mortalities resulted from predation by badgers, skunks, or weasels (the other mortality was caused by collision with a vehicle). From 1992 to 1996, adult male survival during breeding was between 94 and $100 \%$. All male mortality was caused by avian predators ( $\mathrm{T}$. Wellicome, unpubl. data).

Mortality of birds in the post-fledging period has been documented for two consecutive years near Hanna, using radio-telemetry. Mortality of adult males was quite high between the time of fledging and fall dispersal (late July to late August), totalling $45 \%$ in 1995 and $35 \%$ in 1996; whereas no mortality occurred for females during this same period in either year (Clayton and Schmutz 1997). Mortality of recently-fledged owls was also quite high during this time: $65 \%$ in 1995 and $40 \%$ in 1996 . There was, however, no mortality of adult birds or fledglings between fall dispersal (short pre-migratory movements) and migration in either year. The majority of all post-fledging mortalities in Hanna resulted from avian predation.

Clayton and Schmutz (1997) also used telemetry to examine post-fledging dispersal in the Hanna area. Males dispersed earlier in fall and further from nests than did females, and juveniles dispersed larger distances than did adults.

Burrowing Owls migrate from Alberta between early September and mid-October ( $\mathrm{K}$. Clayton, unpubl. data). Migration routes and the location of wintering grounds are unknown, but the owls probably spend the non-breeding season at least as far south as northern Mexico (James 1992). Nest sites in Alberta may be reoccupied in subsequent years, but often by different individuals (Schmutz 1989). Nest-site fidelity has not been well documented (Schmutz 1989), making it difficult to reliably estimate overwinter mortality. Schmutz (1989) used a correction factor to arrive at an approximate over-winter survival rate of $56 \%$ for adults that breed in the Hanna area.

\section{DISTRIBUTION}

1. Alberta. - Burrowing Owls are distributed sparsely throughout the mixed-grass and dry mixed-grass ecoregions of Alberta (Scobie 1993). Historically, the owls were somewhat common in the fescue grass ecoregion and in the southern part of the aspen parkland as far north as Wainwright (Wedgwood 1978), but their range has since contracted so that the species now occurs only sporadically in these two areas. The present range for the Burrowing Owl in Alberta spans from the Saskatchewan border west to Milk River, Lethbridge, and Strathmore (Figure 2). The northern boundary of the range runs just north of Drumheller, Hanna, and Youngstown.

2. Other Areas. - The distribution of the Burrowing Owl in prairie Canada has contracted considerably over the last quarter century, particularly on the northern and eastern periphery (Figure 2). In the 1970s, Burrowing Owls were found as far north as Saskatoon and Yorkton, and as far east as Winnipeg. Today, they are seldom found north of Regina and Weyburn and are essentially extirpated from Manitoba (see "Population Size and Trends"). In British Columbia, Burrowing Owls are presently found only in the vicinity of Kamloops, where captive-bred birds have been released in recent years (D. Low, pers. comm.).

Within broad range limits in North America (Figure 3), the occurrence of the western Burrowing Owl is variable in open, welldrained grasslands, steppes, deserts, prairies, 


\section{Legend}

$1970-1977$

$1978-1988$

1993

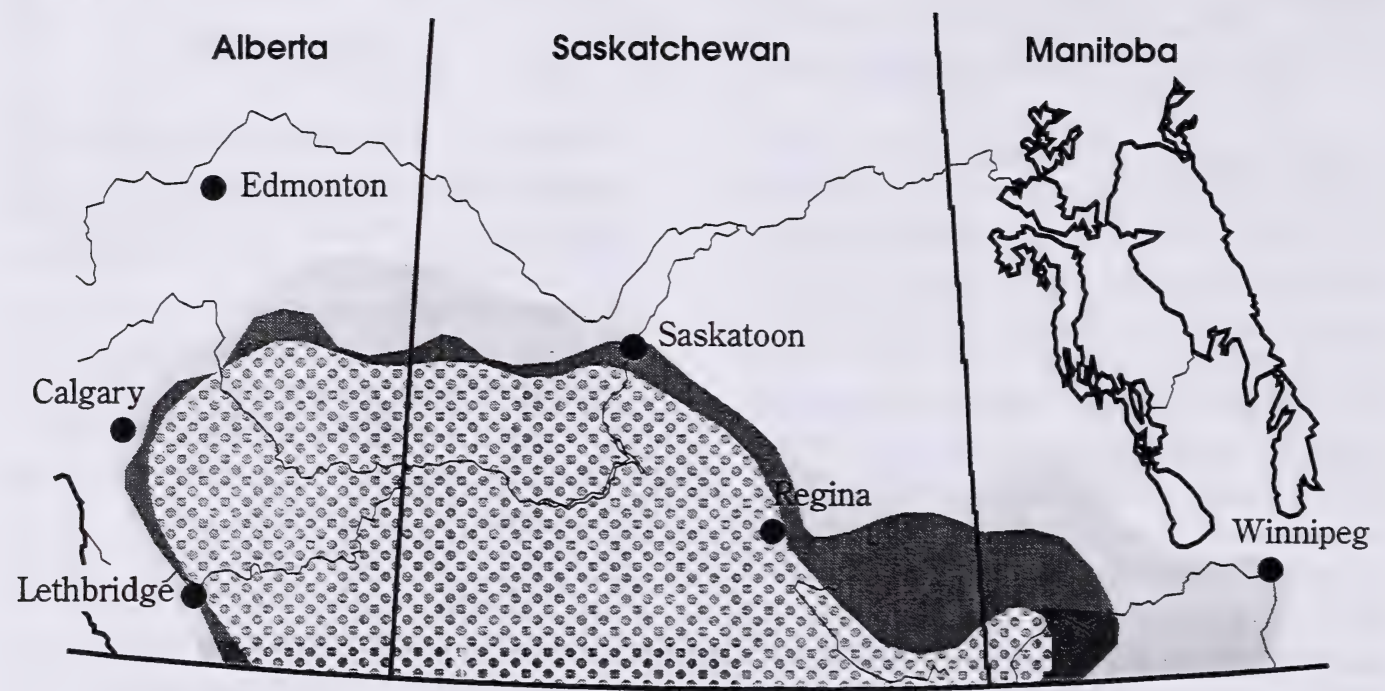

Figure 2. Recent range contraction of the Burrowing Owl in prairie Canada (modified from Wellicome and Haug 1995). Contraction has been particularly evident on the northern and eastern edges of the range, and as of 1997 , the species is virtually extirpated in Manitoba.

and agricultural lands (Haug et al. 1993). The winter distribution of the Canadian owl population is unknown, but is thought to be south of the United States-Mexico border (James 1992), or in coastal Texas (G. Holroyd, pers. comm.). British Columbia's owls seem to migrate south along the west coast, wintering in southern California or northwestern Mexico; however, a small number of owls have been reported overwintering in the Lower Mainland, the southern end of Vancouver Island (Howie 1980), and most recently near Kamloops (D. Low, pers. comm.).
The distribution of the western Burrowing Owl in Mexico is not well known, but preliminary surveys and a review of museum specimens showed that their major winter range is in the northern states of Chihuahua and Coahuila and the coastal states of Tamaulipas and Veracruz along the Gulf of Mexico (G. Holroyd, pers. comm.). Historically, there have been occasional reports of this subspecies as far south as southern Mexico and Guatemala, but these have been only sporadic and no breeding records are known for these areas. 


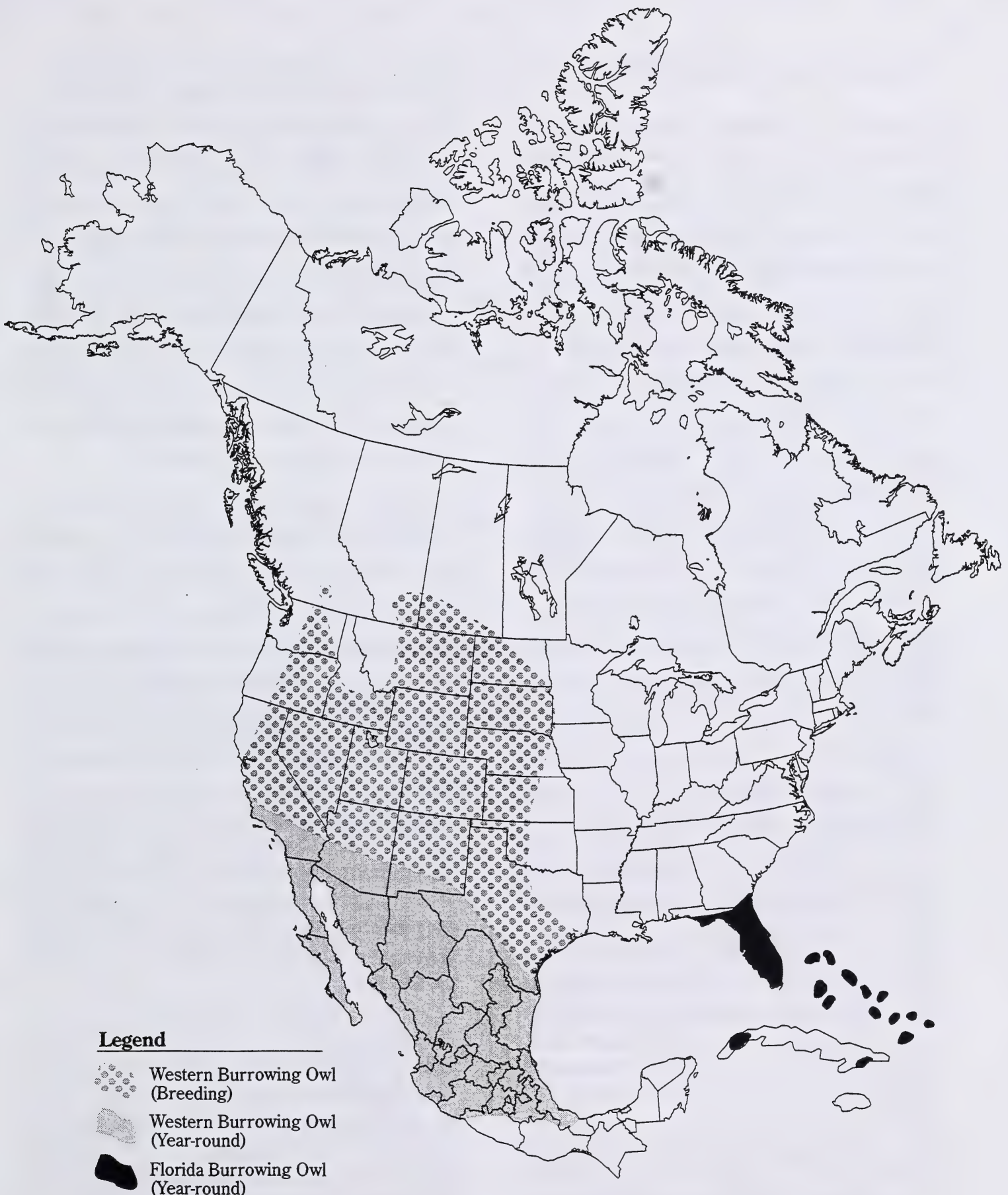

Figure 3. Breeding and year-round distributions of the Burrowing Owl in North America. 


\section{POPULATION SIZE AND TRENDS}

1. Alberta. - Censusing a species like the Burrowing Owl, which exists in small aggregations spread thinly over vast areas of land, can be quite difficult. However, reliable survey techniques, which use playback of recorded Burrowing Owl calls, have recently been developed (Haug and Didiuk 1993, Schmutz and Wood 1992). When used in combination with random sampling over an extensive area, such techniques can produce relatively accurate, scientifically-rigorous estimates of population size at a fairly large scale (Prescott 1993, Schmutz 1994). Unfortunately, many hectares of land must be searched to achieve adequate precision (low variance) for population estimates, making this method extremely labour intensive. In 1994 and 1995, randomly-chosen blocks of habitat were surveyed in a total of 24 Wildlife Management Units in Alberta (Schmutz 1996). Counts were conducted on 3,431 quarter sections, or $3.9 \%$ of the total grassland area in the province. The resulting population estimate was 481 nesting pairs ( $95 \%$ confidence interval $=257$ to 705 pairs). The area that was sampled comprised $57 \%$ of the Burrowing Owl's provincial range. Assuming that density and distribution were similar in the remainder of the species' range in Alberta, an estimated 842 breeding pairs occurred in the province (Schmutz 1996). This suggests that the provincial population has decreased from approximately 1000 pairs in 1990 (Haug and Didiuk 1991) and from more than 1500 pairs in 1978 (Wellicome and Haug 1995).

Long-term data have been gathered for one study population in the Hanna region. While studying the owls' reproduction and diet over a 10-year period, Josef Schmutz and his colleagues monitored changes in the size of the local population of breeding owls.
Although search effort varied somewhat from year to year, an overall decline in the number of nests in the study area was apparent (J. Schmutz, unpubl. data; Figure 4). Local landowners, who have had owls on their property for "as long as they can remember", now report that there are no owls on their land (J. Schmutz, pers. comm.). To get a more reliable index of local population change, the researchers used consistent yearly searcheffort to survey permanent habitat blocks near Hanna (Schmutz 1994). Over a seven-year period, repeated surveys of the same 104 quarter sections, have revealed a decline of three owl pairs per year (Figure 4).

Using the same methodology as Schmutz (1994), 128 quarter sections in eight permanent survey blocks have been monitored in the Eastern Irrigation District east of Brooks (Wildlife Management Division, unpubl. data). Four counts completed over the past five years indicate an increase from six pairs in 1993 to 13 pairs in 1997 (Figure 4). Although this is a relatively small study area, and results should be interpreted cautiously, these blocks are the only area in Canada that suggest a stable or increasing local population of Burrowing Owls. A better understanding of the interplay between land use, limiting factors and the population of owls in this area may provide important information on habitat management and population restoration techniques.

At present, the most extensive quantitative data for gauging recent changes in Alberta's owl population are provided by the private land-steward program, Operation Burrowing Owl (OBO; see Scobie 1993 for detailed description). This program relies on the thousands of rural landowners within the Burrowing Owl's range to enroll if owls nest on their property, and to thereafter report the number of pairs on an annual basis. Such data 


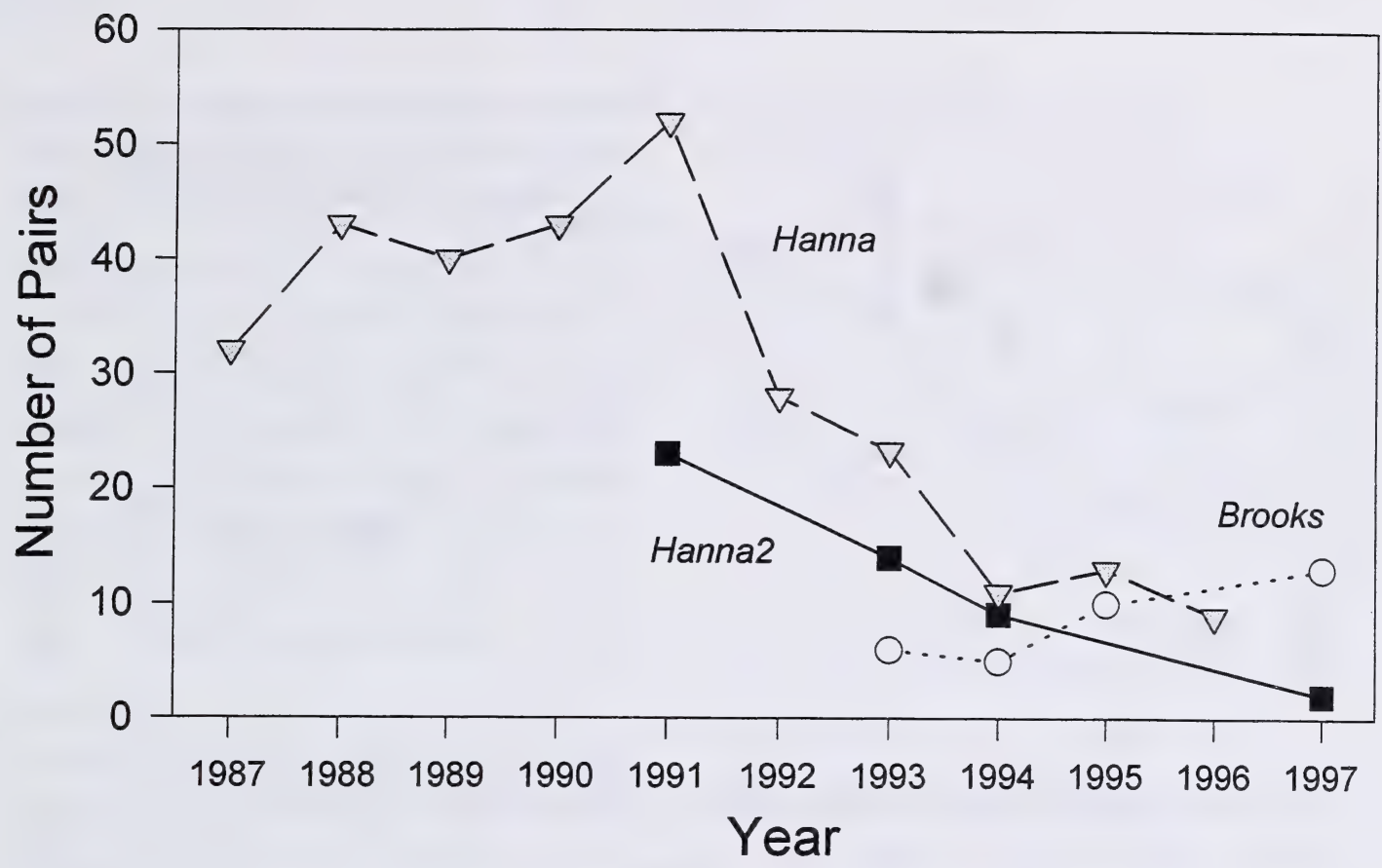

Figure 4. Number of owl pairs recorded in intensive study areas in Alberta. For the line labelled "Hanna", search effort was not consistent from year to year, whereas for the lines labelled "Hanna2" and "Brooks", effort was consistent over time inside permanent habitat blocks (104 and 128 quarter sections, respectively).

appear to be useful for estimating population trends at a large scale (refer to Wellicome and Haug 1995 for discussion). Members who do not respond are phoned in an attempt to collect information from all land locations. As of 1995 , OBO had 243 agreements with landowners who were monitoring 26,371 ha of grassland habitat in Alberta. Figure 5 shows the total number of owl pairs reported by OBO members in Alberta. Over the first three years of the program, the number of reported owls increased in parallel with the number of members, but declined substantially between 1991 and 1996, despite a continued increase in the number of members. Thus, the average number of pairs reported per member has declined substantially since the program's inception.

2. Other Areas. - Breeding Bird Surveys, conducted on 16 routes in Canada's prairie ecozone, show a significant, two percent average annual decline in Burrowing Owl sightings over the last 30 years (1964 to 1994; Kirk and Hislop in press). When the Burrowing Owl was listed as "threatened" by the Committee on the Status of Endangered Wildlife in Canada (COSEWIC) in 1978, its population in Canada likely exceeded 3000 pairs and was declining. As of 1990, the steadily-declining prairie population was estimated at roughly 2500 pairs. Three or four 


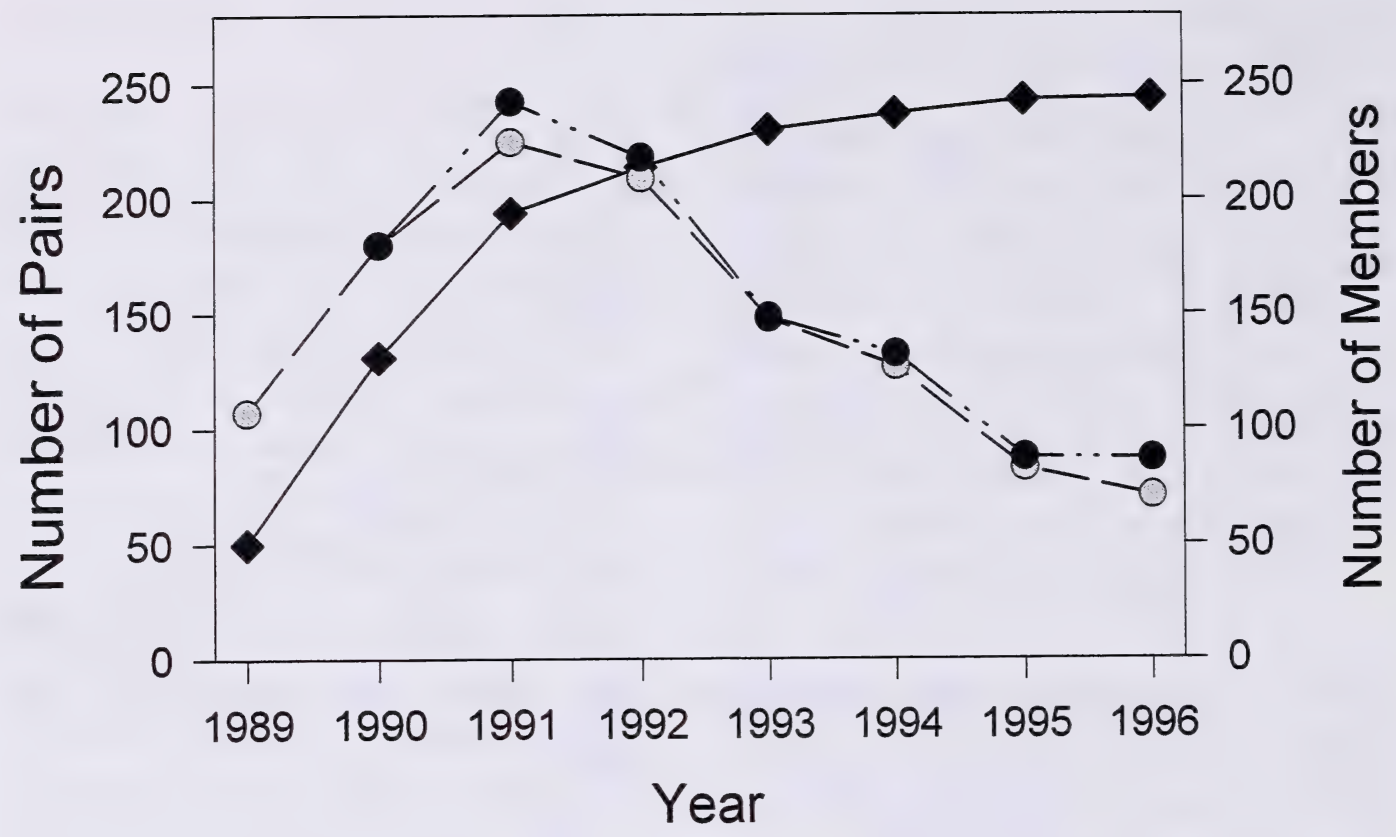

Figure 5. Number of owl pairs reported by Operation Burrowing Owl members in Alberta (shaded circles), and a more accurate estimate of the number of pairs after correcting for members that did not respond to the survey (solid circles). A decline is apparent, despite a quadrupling of members since 1989 (diamonds). Modified from Scobie (1996).

years later the population estimate for prairie Canada was between 1010 and 1685 pairs (Wellicome and Haug 1995).

Landowners enrolled in Saskatchewan's Operation Burrowing Owl program have been reporting the number of owls on their land since 1987. Estimates derived from these data suggest a severe and steady decline of Burrowing Owl numbers in that province (Wellicome and Haug 1995). This decline is evident despite a steady increase in the number of program members (enrolment has doubled since 1987). Although Wedgwood (1978) estimated approximately 100 pairs of owls in Manitoba before 1977, and B. Ratcliffe reported 76 pairs in 1982 , there is now only one pair of owls breeding in Manitoba (K. De Smet, pers. comm.). The Burrowing Owl has, therefore, been effectively extirpated from the province of Manitoba.

Of nineteen state wildlife agencies polled in the United States (James in press), nine reported decreases in their Burrowing Owl populations, and none reported increases. The "educated guesses" collected from this poll provide an estimate of between 17,000 and 82,000 breeding pairs in the United States as of 1992 (excluding the Florida subspecies). Analysis of Christmas Bird Count data between 1954 and 1986 indicates the number of western Burrowing Owls wintering in the 
southern United States has declined since the mid-1970s at a rate of more than three percent per year (James and Ethier 1989). Analyses of the most recent Christmas Bird Counts reveal that this decline has continued $(\mathrm{H}$. Trefry, pers. comm.). However, such counts may not represent Canadian owls, which are thought to winter in Mexico (James 1992). Trends for Mexico's owl populations are unknown, as there are too few Christmas Bird Count routes to provide reliable yearly population indices in that country (H. Trefry, pers. comm.).

\section{LIMITING FACTORS}

Limiting factors for Burrowing Owls are considered to be those factors that increase mortality of juveniles or adults, decrease either productivity of breeders or the proportion of individuals that breed, or reduce habitat quality. I discuss only those limiting factors that are either directly or indirectly related to human activities.

1. Habitat Loss and Degradation. - During this century on the Canadian prairies, the amount of pasture has declined substantially within the Burrowing Owl's range (Wellicome and Haug 1995). Every five years, Agriculture Canada tallies land use associated with farming and ranching. The agricultural census data show that tame and native pasture habitat within the Burrowing Owl's range (census divisions 1 to 7) declined over the past quarter century in Alberta (Figure 6). From 1966 to 1991, the amount of total farm area allocated as pasture within the owl's range (as defined in Wedgewood 1978) decreased by approximately eight percent $(664,330 \mathrm{ha})$. The most striking loss of grassland habitat occurred between 1976 and 1986, the decade that followed a peak in wheat prices. Nevertheless, Alberta has retained much of its pasture ( $46 \%$ of land in Agriculture Canada

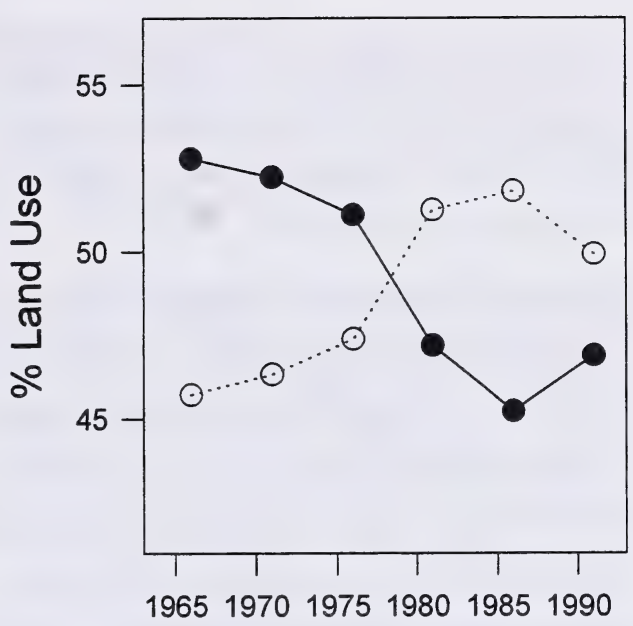

Year

Figure 6. Land use change (solid circles=tame and native pasture; open circles= cultivation) over time within the Burrowing Owl's range in Alberta.

census), compared to Saskatchewan (26\%) and Manitoba (19\%). It should be stressed that pasture represents Burrowing Owl habitat only at a very coarse level because this category also contains land not used by Burrowing Owls for nesting (e.g., rocky soil, hilly terrain, and low land that occasionally floods). The land systems that Burrowing Owls select, such as flat lacustrine land with few rocks (Harris and Lamont 1985), are also favoured for farming, and thus have undoubtedly declined at a faster rate than has pasture in general. Levels of fragmentation are also likely to be highest in heavilycultivated areas and, thus, in areas preferred by Burrowing Owls for nesting. Habitat fragmentation could interrupt the normal flow of individuals between suitable sites, or it could increase nest predation (Verner 1992, Wilcove et al. 1986) by predators that thrive in highly-cultivated regions. However, the 
decline in availability of nesting habitat, and the concomitant increase in fragmentation, appeared to cease about a decade ago (Figure 6 ), yet the Burrowing Owl population continues its steady decline.

At present, the evidence for habitat limitation in Alberta's Burrowing Owls is equivocal. Many researchers point out that the owl decline has caused habitat, which until recently contained owls, to become unoccupied, suggesting that habitat is no longer saturated. In Alberta, $71 \%$ of $\mathrm{OBO}$ sites - all of which had, at some time since 1989, been occupied by owls - were unoccupied as of 1995. The condition of this habitat has a reportedly remained unchanged.

Habitat conditions elsewhere on the continent may affect Burrowing Owl populations during migration or on the wintering grounds. In general, grassland in the United States was cultivated extensively over the last century and is heavily-fragmented, although the Conservation Reserve Program has recently led to small increases in permanent grass cover (Johnson and Schwartz 1993). In addition, a century of extensive prairie dog eradication in both the United States and Mexico has undoubtedly had a negative effect on the quality of Burrowing Owl habitat for migration and for wintering (Miller et al. 1994; G. Holroyd, pers. comm.).

\section{Mortality on Migration or Wintering} Grounds. - Over-winter mortality is extremely difficult to measure in long-distant migrants that do not show high fidelity to their nest sites. Mortality cannot be accurately estimated by the recovery of Burrowing Owl carcasses or aluminum bands because the owls and their bands are quite small and the birds probably winter in the neotropics. Mortality must therefore be deduced from survival, based on resightings of live, banded birds on breeding grounds. Unless site fidelity is $100 \%$, this method invariably overestimates mortality (Haas and Sloane 1989) because birds emigrating from the study area are assumed to be dead. Resighting of banded, adult owls in Hanna ranged from 47 to $58 \%$ (Haug et al. 1993). Deciding whether mortality rates are "high" is somewhat subjective because there are no migratory populations for comparison that are not declining.

3. Pesticides. - Pesticides can affect populations both directly, by causing adult mortality and lowering reproductive performance (James and Fox 1987), and indirectly, by lowering the availability of prey (Brusnyk and Westworth 1987) or by eliminating burrowing mammals. Nothing is known about mortality of migrating or wintering Burrowing Owls caused by pesticide exposure. Similarly, no research has been conducted in Alberta to investigate the direct effects of pesticides on breeding Burrowing Owls. However, an examination of research conducted in Saskatchewan may be relevant to Alberta's owls, if one assumes they are exposed to similar potential toxicants.

In southern Saskatchewan, James et al. (1990) observed no mortality of owls nesting in pastures where ground squirrels were poisoned with strychnine. Although both the number of successful nests and the number of young produced per successful nest in the study were lower in treated than in untreated pastures, the differences were not statistically significant. However, the ability to detect significant differences was probably low given the small number of nests included in the study. 
The poisoning of ground squirrels or prairie dogs may also have indirect negative effects on Burrowing Owls. Reducing or eliminating populations of burrowing animals lowers the quality of sites for Burrowing Owls, or makes formerly-suitable areas unsuitable for nesting (James et al. 1991).

Haug (1985) examined carcasses of 11 fledgling and adult Burrowing Owls which died near Saskatoon, SK, for traces of organochlorines. Five of the 11 birds contained low levels of DDE (0.04 to 0.40 $\mathrm{ppm}$ ) and DDD. One of the five showing DDE also contained low levels of DDT $(0.02$ ppm). Presumably it would only be adult birds, which had already spent time in another country during winter, that would have picked up DDT, as this pesticide is no longer used in the United States or Canada. However, Haug (1985) did not provide information on how contaminant levels in adults compared to those in fledglings (Haug 1985).

Carbofuran is a broad-spectrum, systemic and stomach insecticide belonging to the carbamate class of cholinesterase-inhibiting chemicals. It is sprayed on cereal and forage crops to reduce damage caused by grasshoppers. In Saskatchewan, exposure to carbofuran within $50 \mathrm{~m}$ of nest burrows was associated with a $54 \%$ reduction in the number of young per nest and a $50 \%$ reduction in the proportion of pairs raising one or more young relative to controls (James and Fox 1987).

Research on potential indirect effects of pesticide use in southern Alberta suggests that food availability may be lowered by the application of carbofuran. A considerable reduction in the number of invertebrate prey occurred immediately following carbofuran spraying (Anonymous 1993). In addition, survival of tagged deer mice and meadow voles in grassland sprayed for grasshopper control was $40 \%$ and $33 \%$ less, respectively, than that of unsprayed populations (Brusnyk and Westworth 1987).

4. Predation. - Agricultural practices and the extirpation of Wolves (Canis lupus) from the prairies have encouraged increases in many predator populations (Sargeant et al. 1993). Populations of Red Foxes (Vulpes vulpes), Coyotes, and Striped Skunks are thought to have grown considerably since historic times (Rosatte 1987, Sargeant et al. 1993, Voigt 1987, Voigt and Berg 1987). These species thrive in agricultural areas despite persecution by humans. The increased number of trees in the prairies, which resulted from fire suppression and planting (e.g., shelter belts), has also allowed some avian predator populations to increase (Schmutz et al. 1980). Great Horned Owls, Swainson's Hawks, and Red-tailed Hawks are found in greater abundances than they were on the previouslytreeless plains of the prairies. The provision of den sites in farm buildings allowed the range of another potential predator, the raccoon, to expand northward well into the Canadian prairies, where they were absent in the past (Sanderson 1987).

5. Collision with Vehicles. - Available data suggest that effects of vehicle mortality on Burrowing Owl populations in Alberta are small (K. Clayton, pers. comm.). Of 44 adults and recently-fledged owls fitted with radiotransmitters in the Hanna study area, none were hit by vehicles. During 11 years of research (1986 to 1996, inclusive) conducted on the same study site during and prior to the telemetry work, five owls were found dead on roads within the study area, and of $780 \mathrm{owls}$ banded on the site between 1986 and 1996, none have been returned as vehicle mortalities 
off of the study site. A grader operator near Hanna, whose route covered roads in an area of $2300 \mathrm{~km}^{2}$, found three dead Burrowing Owls in 1992. This represents one percent of the total number of owls expected to be in the area that year, considering the density of owls and their estimated productivity (J. Schmutz, pers. comm.).

Collisions with vehicles should be more frequent in areas where highways and grid roads are more numerous. Twelve per cent of owls that had radio-transmitters during the post-fledging period were killed by vehicles on the Regina Plain study area (K. Clayton, unpubl. data). All of these mortalities occurred on grid roads near one farm. In this same study area, less than $0.5 \%$ of owls without transmitters were found or reported dead on roads each year from 1992 to 1996 (T. Wellicome, unpubl. data); however, many vehicle mortalities may go undetected because they decompose or are scavenged.

6. Shooting. - At a distance, Burrowing Owls can easily be mistaken for ground squirrels. Consequently, it is possible that some owls are shot accidently each year (Hjertaas et al. 1995). However, given that such incidents probably occur infrequently, shooting mortality likely has little or no direct effect on the overall owl population in Alberta. The shooting of burrowing mammals may have indirect negative effects on Burrowing Owls, by lowering the availability of nest and roost burrows.

\section{STATUS DESIGNATIONS}

1. Alberta. - The Burrowing Owl was classified as an "endangered animal" in Alberta under the Alberta Wildlife Act in 1987. The species was also included on Alberta's "Red List" in 1991 (Alberta Fish and
Wildlife 1991), indicating its provincial population was in danger of declining to the point of becoming nonviable. The reasons given for this listing were the dramatic declines in the provincial and national populations, continued cultivation of nest sites, loss of ground squirrels, and pesticide use. For these same reasons, the Burrowing Owl was again categorized as a "Red List" species in the 1996 review of the status of Alberta wildlife (Alberta Wildlife Management Division 1996).

2. Other Areas. - The Burrowing Owl is legally classified as "endangered" in both Manitoba and British Columbia, and is protected under the Wildlife Protection Act in Saskatchewan (Hjertaas et al. 1995).

Nationally, the relatively large but declining Burrowing Owl population was declared "threatened" in 1979 (Wedgwood 1978) by the Committee On the Status of Endangered Wildlife In Canada (COSEWIC). The "threatened" status was upheld in 1991 with the recommendation that the species be considered "endangered" if the population decline persisted (Haug and Didiuk 1991). Intensive and extensive monitoring for an additional four years indicated the decline was ongoing, and the status of the Burrowing Owl was subsequently changed to "endangered" in Canada in 1995 (Wellicome and Haug 1995). In that same year, the National Recovery Plan for the Burrowing Owl was approved (Hjertaas et al. 1995). Its primary objective is to reverse the decline in Canada, and then maintain a stable or increasing population of greater than 3000 pairs for at least 10 years.

In the United States, the Burrowing Owl has been on the Audubon Society's "Blue List" since 1972, and was given "Special Concern" status in 1982 and 1986 (James and Ethier 
1989). The species is listed as "endangered" in Iowa and Minnesota, and "of special concern" in California, Idaho, Montana, North Dakota, Oklahoma, Oregon, South Dakota, Utah, Washington, and Wyoming (Haug et al. 1993). The species has no special status in the seven other states within its western range (James in press).

The status of the Burrowing Owl in Mexico is unknown. Currently, Mexico has no system for legally classifying bird species (G. Holroyd, pers. comm.).

\section{RECENT MANAGEMENT IN ALBERTA}

\section{Habitat Securement, Protection, and} Enhancement. - The Operation Burrowing Owl (OBO) program (Alberta Fish and Game Association) enlists farmers, ranchers, and other rural landowners in southern Alberta as volunteers in the protection of active, and previously active, Burrowing Owl nesting areas. Participating landowners sign a voluntary agreement to preserve owl nesting sites for a period of five years, at which time the agreement may be renewed. Through such arrangements, 243 members of $\mathrm{OBO}$ are currently protecting 26,371 ha (the equivalent of 407 quarter sections) of grassland habitat in Alberta. Suggestions for habitat preservation or improvement are provided in annual newsletters mailed to all members.

Burrowing Owls are a species of concern in environmental impact assessments for pipelines, mining, and other industrial activities (S. Brechtel, pers. comm.). Pipeline routes are planned so as to avoid Burrowing Owl nesting areas if possible, and mitigation techniques, such as the installation of artificial nest burrows, are sometimes employed (D. Scobie, pers. comm.).
2. Research. - Research on Burrowing Owl ecology has been conducted in Alberta by Dr. Josef Schmutz and associates, since 1986. Research has focussed on habitat use and characteristics (Schmutz 1989), return rates and annual survival (Schmutz 1989, Schmutz et al. 1991a), productivity (Clayton and Schmutz 1995), diet (Schmutz et al. 1991b), census techniques (Schmutz 1996, Schmutz and Wood 1992), and genetic and morphological comparison of populations (Wilde 1995). Recently, Kort Clayton and Josef Schmutz used radio-telemetry to study the post-fledging ecology of Burrowing Owls near Hanna (Clayton and Schmutz 1997). More than 780 Burrowing Owls have been banded in the Hanna area since 1987.

Geoff Holroyd, of the Canadian Wildlife Service, has initiated investigations into the seasonal distribution, ecology, and behaviour of Burrowing Owls in northern Mexico and Texas, in an effort to narrow the search for the wintering grounds of the Canadian owls ( $G$. Holroyd, pers. comm.).

\section{SYNTHESIS}

The Burrowing Owl is widely- but sparselydistributed throughout the mixed-grass and dry mixed-grass ecoregions of Alberta. It is now an uncommon bird in the province, as population estimates suggest there are fewer than 850 pairs remaining. Moreover, this remnant population is declining at an alarmingly fast and steady rate. The population index calculated from Operation Burrowing Owl data has decreased by $65 \%$ since 1991, despite an increase in the number of members reporting the presence or absence of owls on their land. Intensive population monitoring in the Hanna region provides additional evidence for this ongoing decline. Much of the habitat in Alberta that used to 
contain owls is now unoccupied, and the Burrowing Owl's provincial distribution has been reduced, such that it is now absent from a considerable portion of its historic range.

Research in the Hanna area suggests that Burrowing Owls are not faring well demographically. Owl productivity has declined over the last 11 years, local recruitment has been low, and over-winter mortality appears to have been quite high. Past modification of the prairie environment has increased predator populations, and thus may have reduced nesting success and/or elevated mortality of fledglings and adult males. In some areas, pesticide use may be having direct and indirect effects on the owl population. Pesticide use and habitat modification may also have negative impacts during migration and on the wintering grounds; however, research on these and other potential limiting factors during the nonbreeding season has been hampered by a lack of information on the whereabouts of the owls when they are outside of Alberta.

The primary objective of the National Burrowing Owl Recovery Plan is to reverse the population decline and subsequently maintain a stable or increasing population averaging at least 3000 pairs on the Canadian prairies, including at least 1500 pairs in Alberta (Hjertaas et al. 1995). As the population continues to decline, we get further and further from accomplishing this objective. Unless the population trend is reversed, all indications are that the Burrowing Owl will be extirpated from Alberta and from Canada within a couple of decades.

If we are to reverse the population decline in Alberta, we will need a better understanding of the ecology of the Burrowing Owl. Where do the owls winter? What route(s) do they use for migration? What factors could be causing high mortality away from the breeding grounds? How are burrowing mammal populations and habitats changing both on and off the breeding grounds? Within Alberta, we need to increase our understanding of the owl's nesting-habitat requirements and of its nocturnal foraging behaviour. Why has productivity declined over the decade? What effects, if any, have habitat fragmentation had on dispersal and predation rates? Such insights will greatly aid future management and conservation initiatives, and could improve the outlook for the species in the province. 


\section{LITERATURE CITED}

Alberta Fish and Wildlife. 1985. A policy for the management of threatened wildlife in Alberta. Alberta Fish and Wildlife, Edmonton, AB. 34 pp.

Alberta Fish and Wildlife. 1991. The status of Alberta wildlife. Alberta Fish and Wildlife, Edmonton, AB. 49 pp.

Alberta Wildlife Management Division. 1996. The status of Alberta wildlife. Alberta Natural Resources Service, Edmonton, AB. $44 \mathrm{pp}$.

Anonymous. 1993. Special review of carbofuran insecticide: effects on avian fauna and value to agriculture. Discussion Document. Plant Industry Directorate, Agriculture Canada, Ottawa, ON. 53 pp.

Bent, A. C. 1938 . Life histories of North American birds of prey. U.S. Natl. Mus. Bull. 170. 482 pp.

Brusnyk, L. M., and D. A. Westworth. 1987. Effects of carbofuran on unconfined small mammal populations in southern Alberta. Unpubl. rept. by D. A. Westworth and Associates, Ltd. for Alberta Agriculture, Edmonton, $\mathrm{AB}$.

Clayton, K. M., and J. K. Schmutz. 1995. Dispersal, survival, and habitat use by Burrowing Owls in Alberta. Progress report prepared for Alberta Natural Resources Service, Edmonton, AB. 19 pp.

Clayton, K. M., and J. K. Schmutz. 1997. Post-fledging ecology of Canadian Burrowing Owls. Unpubl. report, Univ. Saskatchewan, Saskatoon, SK. 14 pp.
COSEWIC. 1996. Canadian species at risk. Committee on the Status of Endangered Wildlife in Canada, Ottawa, ON. 18 pp.

Gleason, R. S. 1978. Aspects of the breeding biology of Burrowing Owls in southeastern Idaho. M.S. Thesis Univ. Idaho, Moscow, ID. $47 \mathrm{pp}$.

Haas, C. A., and S. A. Sloane. 1989. Low return rates of migratory Loggerhead Shrikes: winter mortality or low site fidelity? Wilson Bull. 101: 458-460.

Harris, W. C., and S. M. Lamont. 1985. Saskatchewan Burrowing Owls: breeding distribution and habitat utilization. Unpubl. report by Prairie Environmental Services, Inc., for the Saskatchewan Natural History. Society and Saskatchewan Parks and Renewable Resources, Regina, SK. 79 pp.

Haug, E. A. 1985. Observations on the breeding ecology of Burrowing Owls in Saskatchewan. M.Sc. thesis, Univ. Saskatchewan, Saskatoon, SK. 89 pp.

Haug, E. A., and A. B. Didiuk. 1991. Updated status report on the Burrowing Owl in Canada. Prepared for the Committee on the Status of Endangered Wildlife in Canada, Ottawa, ON. 29 pp.

Haug, E. A, and A. B. Didiuk. 1993. Use of recorded calls to detect Burrowing Owls. J. Field Ornithol. 64: 188-194.

Haug, E. A., B. A. Millsap, and M. S. Martell. 1993. Burrowing Owl (Speotyto cunicularia). In The birds of North America, No. 61 (A. Poole and F. Gill, eds.). The Academy of Natural Sciences, Philadelphia, PA, and The American 
Ornithologists' Union, Washington, DC. $20 \mathrm{pp}$.

Haug, E. A., and Oliphant, L. W. 1990. Movements, activity patterns, and habitat use of Burrowing Owls in Saskatchewan. J. Wildl. Manage. 54: 27-35.

Hjertaas, D. G., S. Brechtel, K. De Smet, O. Dyer, E. A. Haug, G. Holroyd, P. C. James, and J. K. Schmutz. 1995. National recovery plan for the Burrowing Owl. A report prepared for the Committee for the Recovery of Nationally Endangered Wildlife. Canadian Wildlife Federation, Ottawa, ON. 33 pp.

Hjertaas, D. G., and W. Lyon. 1987. A stratified random survey for Burrowing Owls on the Weyburn (62E) and Regina (72I) map areas. Sask. Parks, Rec., and Culture, Wildl. Tech. Rept. 87-2. 15 pp.

Howie, R. 1980. The Burrowing Owl in British Columbia. Pp. 88-95 in Threatened species and habitats in British Columbia and the Yukon (R. Stace-Smith, ed.). British Columbia Ministry of Environment, Victoria, B.C.

James, P. C. 1992. Where do Canadian Burrowing Owls spend the winter? Blue Jay 50: 93-95

James, P. C. In press. The current status of the Burrowing Owl in North America. In Proceedings of the Burrowing Owl Symposium, Sacramento, CA. (J. L. Lincer, ed.). J. Raptor Res. Special Publication 9.

James, P. C., and T. J. Ethier. 1989. Trends in the winter distribution and abundance of
Burrowing Owls in North America. Amer. Birds 43: 1224-1225.

James, P. C., T. J. Ethier, G. A. Fox, and M. Todd. 1991. New aspects of Burrowing Owl biology. Pp. 226-227 in Proceedings of the second endangered species and prairie conservation workshop (G. L. Holroyd, G. Burns, and H. C. Smith, eds.). Prov. Museum Alberta Nat. Hist. Occas. Paper No. 15, Edmonton, Alberta. 284 pp.

James, P. C., and G. A. Fox. 1987. Effects of some insecticides on productivity of Burrowing Owls. Blue Jay 45: 65-71.

James, P. C., G. A. Fox, and T. J. Ethier. 1990. Is the operational use of strychnine to control ground squirrels detrimental to Burrowing Owls? J. Raptor Res. 24: 120123.

Johnson, D. H., and M. D. Schwartz. 1993. The Conservation Reserve Program and grassland birds. Conserv. Biol. 7: 934-937.

Kirk, D. A., and C. Hyslop. In press. Population status and recent trends in Canadian raptors: a review. Conservation Biology.

Miller, B., G. Ceballos, and R. Reading. 1994. The prairie dog and biotic diversity. Conserv. Biol. 8: 677-681.

National Research Council. 1995. Science and the Endangered Species Act. National Academy Press, Washington, DC. 271 pp.

Plumpton, D. L. 1992. Aspects of nest-site selection and habitat use by Burrowing Owls at the Rocky Mountain Arsenal, Colorado. M.S. Thesis, Texas Tech. Univ., Lubbock, TX. 72 pp. 
Plumpton, D. L., and R. S. Lutz. 1993. Prey selection and food habits of Burrowing Owls in Colorado. Great Basin Natur. 53: 299-304.

Plumpton, D. L., and R. S. Lutz. 1994. Sexual size dimorphism, mate choice, and productivity of Burrowing Owls. Auk 111: 724-727.

Prescott, D. R. C. 1993. An approach to estimating and monitoring population size of Burrowing Owls (Athene cunicularia) and other grassland species in Alberta. Unpubl. rept. for Alberta Fish and Wildlife Services, Red Deer, AB. 13 pp.

Rosatte, R. C. 1987. Striped, Spotted, Hooded, and Hog-nosed Skunk. Pp. 598613 in Wild furbearer management and conservation in North America (M. Novak, J. A. Baker, M. E. Obbard, and B. Malloch, eds.). Ontario Trappers Association, North Bay, ON. 1150 pp.

Sanderson, G. C. 1987. Raccoon. Pp. 486499 in Wild furbearer management and conservation in North America (M. Novak, J. A. Baker, M. E. Obbard, and B. Malloch, eds.). Ontario Trappers Association, North Bay, ON. 1150 pp.

Sargeant, A. B., R. J. Greenwood, M. S. Sovada, and T. L. Shaffer. 1993. Distribution and abundance of predators that affect duck production - prairie pothole region. U. S. Fish Wildl. Serv. Res. Publ. No. 194, Washington, D.C. 96 pp.

Schmutz, J. K. 1989. Conservation biology of Burrowing Owls: survival, habitat use, and differences between populations. Unpubl. report, Univ. Saskatchewan, Saskatoon, SK. 22 pp.

Schmutz, J. K. 1994. Counts of breeding Burrowing Owls in southeastern Alberta. Unpubl. report, Univ. Saskatchewan, Saskatoon, SK. 18 pp.

Schmutz, J. K. 1996. A census of breeding Burrowing Owls in southeastern Alberta: 1994-95. Unpubl. report, Univ. Saskatchewan, Saskatoon, SK. 14 pp.

Schmutz, J. K. , S. M. Schmutz, and D. A. Boag. 1980. Coexistence of three species of hawks (Buteo spp.) in the prairieparkland ecotone. Can. J. Zool. 58: 10751089.

Schmutz, J. K., and D. W. Wood. 1992. Determining Burrowing Owl breeding density in a prairie environment. Unpubl. manuscript, Univ. Saskatchewan, Saskatoon, SK. 18 pp.

Schmutz, J. K., D. W. Wood, and G. Wood. 1991a. Burrowing Owl survival. Pp. 228 in Proceedings of the Second Endangered Species and Prairie Conservation Workshop. (G. L. Holroyd, G. Burns, and H. C. Smith, eds.). Prov. Museum Alberta Nat. Hist. Occas. Paper No. 15, Edmonton, AB. $284 \mathrm{pp}$.

Schmutz, J. K., G. Wood, and D. W. Wood. 1991b. Spring and summer prey of Burrowing Owls in Alberta. Blue Jay 49: 93-97.

Scobie, D. 1993. Operation Burrowing Owl (Alberta): 1993 final report. Unpubl. report for Alberta Fish and Game Association, Edmonton, AB. 19 pp. 
Scobie, D. 1996. Operation Grassland Community - 1996 summary. Unpubl. report for Alberta Fish and Game Association, Edmonton, AB. 3 pp.

Verner, J. 1992. Data needs for avian conservation biology: have we avoided critical research? Condor 94: 301-303.

Voigt, D. R. 1987. Red Fox. Pp. 378-392 in Wild Furbearer management and conservation in North America (M. Novak, J. A. Baker, M. E. Obbard, and B. Malloch, eds.). Ontario Trappers Assoc., North Bay, ON. 1150 pp.

Voigt, D. R., and W. E. Berg. 1987. Coyote. Pp. 345-357 in Wild furbearer management and conservation in North America (M. Novak, J. A. Baker, M. E. Obbard, and B. Malloch, eds.). Ontario Trappers Association, North Bay, ON. 1150 pp.

Wedgwood, J. A. 1978. The status of the Burrowing Owl in Canada. A report prepared for the Committee on the Status of Endangered Wildlife in Canada. Can. Wildl. Serv., Ottawa, ON. 83 pp.

Wellicome, T. I. 1994. Taverner award recipient's report: Is reproduction in Burrowing Owls limited by food supply? Picoides 7: 9-10.

Wellicome, T. I. In press. Reproductive performance of Burrowing Owls: effects of supplementary food. In Proceedings of the Burrowing Owl Symposium, Sacramento,
CA. (J. L. Lincer, ed.). J. Raptor Res. Special Publication 9.

Wellicome, T. I., and E. A. Haug. 1995. Second update of status report on the Burrowing Owl Speotyto cunicularia in Canada. Report prepared for the Committee on the Status of Endangered Wildlife in Canada, Canadian Wildlife Service, Ottawa, ON. 32 pp.

Wellicome, T. I., G. L. Holroyd, K. Scalise, and E. R. Wiltse. In press. The effects of predator exclusion and food supplementation on Burrowing Owl (Speotyto cunicularia) population change. $\underline{\text { In Proceedings of the Second International }}$ Symposium: Biology and Conservation of Owls of the Northern Hemisphere (M. J. Peterson and T. H. Nichols, eds.). U. S. Dept. Agr. For. Serv. Gen. Tech. Rept.

Wilcove, D. S., C. H. McLellan, and A. P. Dobson. 1986. Habitat fragmentation in the temperate zone. Pp. 237-256 in Conservation biology: the science of scarcity and diversity. (M. Soulé and B. A. Wilcox, eds.), Sinauer Assoc., Sunderland, MA. $584 \mathrm{pp}$.

Wilde, B. K. 1995. A population genetics study of the Burrowing Owl Speotyto cunicularia by RAPD-PCR analysis. B.Sc. thesis, Univ. Regina, Regina, SK. 82 pp.

Zarn, M. 1974. Burrowing Owl. Rept. No. 11. Habitat management series for unique or endangered species. Bureau of Land Management, Denver, CO. 25 pp. 
APPENDIX. Definitions of selected legal and protective designations.

\section{A. Status of Alberta Wildlife color lists (after Alberta Wildlife Management Division 1996)}

\begin{tabular}{|l|l|}
\hline Red & $\begin{array}{l}\text { Current knowledge suggests that these species are at risk. These species have declined, or are in } \\
\text { immediate danger of declining, to nonviable population size }\end{array}$ \\
\hline Blue & $\begin{array}{l}\text { Current knowledge suggests that these species may be at risk. These species have undergone } \\
\text { non-cyclical declines in population or habitat, or reductions in provincial distribution }\end{array}$ \\
\hline Yellow & $\begin{array}{l}\text { Species that are not currently at risk, but may require special management to address concerns } \\
\text { related to naturally low populations, limited provincial distributions, or demographic/life history } \\
\text { features that make them vulnerable to human-related changes in the environment }\end{array}$ \\
\hline Green & Species not considered to be at risk. Populations are stable and key habitats are generally secure \\
\hline Undetermined & Species not known to be at risk, but insufficient information is available to determine status \\
\hline
\end{tabular}

\section{B. Alberta Wildlife Act}

Species designated as "endangered" under the Alberta Wildlife Act include those defined as "endangered" or "threatened" by A Policy for the Management of Threatened Wildlife in Alberta (Alberta Fish and Wildlife 1985):

\begin{tabular}{|l|l|}
\hline Endangered & A species whose present existence in Alberta is in danger of extinction within the next decade \\
\hline Threatened & $\begin{array}{l}\text { A species that is likely to become endangered if the factors causing its vulnerability are not } \\
\text { reversed }\end{array}$ \\
\hline
\end{tabular}

\section{Committee on the Status of Endangered Wildlife in Canada (after COSEWIC 1996)}

\begin{tabular}{|l|l|}
\hline Extirpated & A species no longer existing in the wild in Canada, but occurring elsewhere \\
\hline Endangered & A species facing imminent extirpation or extinction \\
\hline Threatened & A species likely to become endangered if limiting factors are not reversed \\
\hline Vulnerable & $\begin{array}{l}\text { A species of special concern because of characteristics that make it particularly sensitive to } \\
\text { human activities or natural events }\end{array}$ \\
\hline Not at Risk & A species that has been evaluated and found to be not at risk \\
\hline Indeterminate & A species for which there is insufficient scientific information to support status designation \\
\hline
\end{tabular}

\section{United States Endangered Species Act (after National Research Council 1995)}

\begin{tabular}{|l|l|}
\hline Endangered & Any species which is in danger of extinction throughout all or a significant portion of its range \\
\hline Threatened & $\begin{array}{l}\text { Any species which is likely to become an endangered species within the foreseeable future } \\
\text { throughout all or a significant portion of its range }\end{array}$ \\
\hline
\end{tabular}




\section{List of Titles In This Series}

(as of September 1997)

No. 1 Status of the Piping Plover (Charadrius melodus) in Alberta, by David R. C. Prescott. 19 pp.

No. 2 Status of the Wolverine (Gulo gulo) in Alberta, by Stephen Petersen. $17 \mathrm{pp}$.

No. 3 Status of the Northern Long-eared Bat (Myotis septentrionalis) in Alberta, by M. Carolina Caceres and M. J. Pybus. 19 pp.

No. 4 Status of the Ord's Kangaroo Rat (Dipodomys ordii) in Alberta, by David L. Gummer. 16 pp.

No. 5 Status of the Eastern Short-horned Lizard (Phrynosoma douglassii brevirostre) in Alberta, by Janice D. James, Anthony P. Russell and G. Lawrence Powell. 20 pp.

No. 6 Status of the Prairie Rattlesnake (Crotalus viridis viridis) in Alberta, by Sheri M. Watson and Anthony P. Russell. 26 pp.

No. 7 Status of the Swift Fox (Vulpes velox) in Alberta, by Susan E. Cotterill. 17pp.

No. 8 Status of the Peregrine Falcon (Falco peregrinus anatum) in Alberta, by Petra Rowell and David P. Stepnisky. In Preparation.

No. 9 Status of the Northern Leopard Frog (Rana pipiens) in Alberta, by Greg Wagner. In Preparation.

No. 10 Status of the Sprague's Pipit (Anthus spragueii) in Alberta, by David R. C. Prescott. 14 pp.

No. 11 Status of the Burrowing Owl (Speotyto cunicularia hypugaea) in Alberta, by Troy I. Wellicome. $21 \mathrm{pp}$. 

National Library of Canada

Bibliotheque nationale du Canada

Bibliotheque nationale du Canada

33286513567038 